\title{
APLIKASI TEKNOLOGI ROTATING BIOLOGICAL CONTACTOR (RBC) PADA PENGOLAHAN AIR LIMBAH
}

\author{
Riestidy Dwicaesa Putri \\ Jurusan Teknik Lingkungan, Fakultas Arsitektur Lanskap dan Teknologi Lingkungan, \\ Universitas Trisakti, Jakarta, Indonesia
}

Email korespondensi: riestidy08213035@std.trisakti.ac.id

\begin{abstract}
ABSTRAK
Rotating Biological Contactor adalah salah satu dari teknologi seacara biologis untuk pengolahan air limbah. RBC merupakan alternatif yang sangat unik dan unggul untuk bahan biodegradable dan pembuangan nitrogen karena kelayakan, desain yang sederhana dan pengoperasian yang mudah, kebutuhan lahan yang rendah, konsumsi energi yang rendah, biaya operasi dan pemeliharaan yang rendah dan efisiensi perawatan.
\end{abstract}

Kata Kunci: Air Limbah ; Pengolahan Air Limbah ; RBC ; Teknologi Pengolahan Air

Limbah

\section{PENDAHULUAN}

Di negara-negara berkembang, pembuangan langsung air limbah ke badan air (danau, sungai, dll.), Dan kesulitan mendapatkan air bersih yang memadai merupakan tantangan besar. Pembuangan air limbah tanpa melalui pengolahan memiliki dampak besar pada keanekaragaman perairan, kesehatan masyarakat, dan eutrofikasi (Rininta dan Prayatni, 2018). Oleh karena itu, pengolahan air limbah perlu dilakukan sebelum air limbah dibuang ke badan air penerima. Salah satunya adalah dengan proses pengolahan biologis, telah banyak digunakan dalam pengolahan air limbah karena biaya operasional yang rendah dan efektif dalam mengolah air limbah. Proses pengolahan biologis menggunakan mikroorganisme. Salah satu teknologi pengolahan air seacara biologis adalah proses pengolahan air limbah menggunakan Rotating Biological Contactor (RBC). Tujuan dari pengolahan air limbah secara biologi adalah untuk membersihkan zat organik atau mengubah zat organik yang berbahaya menjadi tidak berbahaya bagi lingkungan. Air limbah yang telah diolah dan dibuang ke badan air harus memenuhi standar baku muku yang ada yaitu Peraturan menteri lingkungan hidup no. 68 Tahun 2016 tentang baku mutu air limbah domestik.

\section{TINJAUAN PUSTAKA}

\section{Rotating Biological Contactor (RBC)}

Rotating Biological Contactor (RBC) banyak diterapkan dalam pengolahan biologis untuk air limbah domestik dan air limbah industri. RBC merupakan alternatif untuk metode konvensional teknologi lumpur aktif dari pengolahan air limbah. Rotating contactor dicirikan dengan stabilitas proses perawatan, pemakaian energi listrik yang rendah, waktu detensi yang pendek, biaya operasional yang rendah dan kemudahan dalam pengoperasian (Joanna,et.al, 2018).

RBC terdiri dari sejumlah cakram paralel yang dipasang tegak lurus pada poros dan berputar secara perlahan (sekitar 1 - 1,6 putaran per menit) dalam tangki berisi air limbah yang akan diolah, dan unit RBC sebagian terendam dalam tangki (biasanya 40\%). Parameter utama desain untuk RBC adalah laju pemuatan hidraulik dan laju pemuatan organik. 
Saat ini, RBC merupakan proses biofilm yang dipilih dalam pengolahan air limbah kota dan industri karena dapat mengolah bahan organic dengan parameter COD mencapai 600 $2000 \mathrm{mg} / \mathrm{L}$. Biomassa dalam cakram RBC adalah peran utama dalam biodegradasi organic (Rongjun Su,et.al, 2015).

RBC memiliki beberapa keunggulan seperti waktu detensi yang pendek, kebutuhan daya yang rendah, konsentrasi biomassa tinggi, menangani berbagai aliran dan menghasilkan lumpur yang rendah (Atieh,et.al, 2018). Efisiensi biodegradasi dalam RBC tergantung pada sejumlah parameter, termasuk kandungan oksigen terlarut dalam air limbah, intensitas aliran air limbah, kandungan senyawa organik, kecepatan rotasi serta sistem konfigurasi, termasuk metode distribusi cairan dan kondisi aerasi (Joanna SzulżykCieplak,et.al, 2018) .

\section{Proses Rotating Biological Contactor (RBC)}

Unit RBC biasanya terdiri dari serangkaian cakram besar, datar atau bergelombang yang berjarak dekar yang dipasangkan pada poros horizontal dan sebagian atau seluruhnya terendam dalam air limbah. Bak yang diisi dengan beberapa penyangga ringan juga dapat digunakan sebagai pengganti cakram konvensional. Poros terus berputar yang digerakkan oleh motor mekanis atau penggerak udara terkompresi dan biofilm dibuat keseluruh area permukaan media, yang memetabolisme bahan organik yang terkandung dalam air limbah. Dalam proses aerobik, rotasi media mendorong transfer oksigen dan mempertahankan biomassa dalam kondisi aerob. Rotasi juga memberikan turbulensi pada permukaan keras dan memungkinkan penghilangan padatan berlebih pada media (Tsukasa,et.al, 2019).

Mikroorganisme yang biasanya dipakai misalnya bakteri, algae, protozoa, fungi dan lain sebagainya tumbuh melekat pada permukaan media yang berputar yang dapat membetuk lapisan yang disebut biofilm (lapisan biologis). Mikroorganisme dapat mengurangi atau menghilangkan senyawa organik yang ada di dalam air limbah serta mengambil oksigen yang terlarut dalam air atau dari udara untuk proses metabolisme sehingga kandungan senyawa organik dalam limbah berkurang (V. Singh,et.al, 2012).

\section{Faktor yang Mempengaruhi Kinerja RBC}

Kinerja RBC tergantung pada beberapa parameter desain, yaitu (Tang Yun-lu,et.al, 2012) :

1. Kecepatan Rotasi

Kecepatan rotasi media $\mathrm{RBC}$ adalah parameter yang sangat penting yang mempengaruhi perpindahan massa nutrisi dan oksigen dalam biofilm dan akibatnya pemindahan substrat. Kecepatan rotasi secara signifikan mempengaruhi efisiensi perawatan. Dengan meningkatkan kecepatan rotasi, turbulensi meningkat dan tingkat oksigen terlarut yang tersedia untuk mikroorganisme dan sebagai hasilnya mereka dapat mendegradasi substrat pada kecepatan yang lebih tinggi. Namun, meningkatnya kecepatan rotasi dapat menyebabkan konsumsi daya yang lebih tinggi, yang mungkin tidak ekonomis untuk aplikasi pengolahan air limbah. Selain itu, jika kecepatan rotasi terlalu tinggi, mikroorganisme akan dilepaskan dari media dan menurunkan kualitas limbah dan menurunkan laju biodegradasi dalam reaktor Jadi harus mempertahankan kecepatan rotasi yang memberikan oksige terlarut maksimum tetapi tidak mengelupaskan biofilm. Kecepatan rotasi tipikalnya $1-10$ rpm untuk RBC.

2. Laju Pembebanan Organik (Organik Loading Rate)

Variasi laju pembebanan organik umumnya dicapai dengan mengubah laju aliran masuk atau HRT, yang juga menghasilkan perubahan pembebanan hidrolik. Untuk sistem tertentu, saat laju pemuatan organik yang diterapkan meningkat, laju 
perpindahan media meningkat dan efisiensi pemindahan menurun. Penurunan efisiensi penghilang substrat dapat menjadi indikasi keterbatasan oksigen terlarut. Pemuatan organik mempengaruhi nitrifikasi dalam unit RBC. Pada tahap awal dimana beban organik tinggi, bakteri heterotrofik menawarkan persaingan yang kuat untuk menggantikan nitrifikasi mereka dalam bioreaktor. Oleh karena itu, desain yang diusulkan dari BOD sebesar $5 \mathrm{~g} / \mathrm{m}^{2}$.d di rekomendasikan untuk proses nitrifikasi.

3. Hydraulic Loading

Kinerja RBC telah berkolerasi dengan pembebanan hidrolik. Meningkatkan laju aliran melalui bioreaktor mengurangi waktu retensi air dalam sistem dan menghasilkan penurunan efisiensi. Dalam kondisi yang ditentukan meningkatkan pemuatan hidraulik juga mengarah pada peningkatan biomassa yang terpasang pada permukaan media RBC.

4. Media RBC

Banyak peneliti yang menggunakan berbagai bahan disk untuk membuat sistem menjadi ekonomis dan intensif energi yang sedikit. Mereka juga mengevaluasi berbagai faktor yang mempengaruhi efisiensi RBC. Media RBC yang digunakan antara lain :
a. Cakram polistiren (Polystyrene Discs)
b. Disk stainless steel yang tertutup
c. Disk plastik bening yang ringan
d. Propylene Discs
e. Cakram plastik keras
f. Cakram plastik akrilik

5. Suhu

Suhu merupakan salah satu faktor penting untuk mengendalikan kecepatan reaksi biologis. Mikroba dari semua jenis telah mengubah tingkat aktivitas pada suhu yang berbeda, pada suhu tertentu mereka mati atau aktivitasnya dihentikan. Jadi, dalam kisaran, karena suhu air limbah meningkat, tingkat biodegrading meningkat dan sebaliknya di semua tahap RBC.

6. Karakteristik Biofilm

Untuk mengoptimalkan penghapusan bahan organik dan senyawa nitrogen dari air limbah dalam RBC, pemahaman yang memadai tentang sifat dinamis dan karakteristik biofilm, unsur utama proses, sangat penting. Biofilm adalah sistem mikroba hidup yang terutama terdiri dari mikroorganisme, polimer ekstraseluler, dan air. Distribusi spasial dari komponen-komponen ini dalam matriks biofilm dapat mempengaruhi fungsi biofilm dan hubungannya dengan lingkungan akuatik secara langsung.

7. Dissolved Oxygen (DO)

Dalam sistem RBC aerobik, biofilm diizinkan terbentuk pada medium, yang sebagian terendam dalam air limbah dan sebagian terpapar ke udara. Rotasi secara bergantian memaparkan biofilm ini ke oksigen atmosfer dan air limbah. Transfer oksigen dari udara ke unit RBC dalam tiga cara yaitu dengan penyerapan oksigen pada film cair di atas permukaan biofilm ketika biofilm berada di udara, dengan transfer oksigen langsung di antarmuka air-air, dan dengan penyerapan oksigen langsung oleh mikroorganisme selama eksposur. Oksigen terlarut sangat penting dalam oksidasi dan nitrifikasi karbon faktor desain paling penting untuk aerobik RBC. Selama operasi, kadar oksigen harus dikontrol dengan baik dan untuk mencegah menjadi faktor pembatas, tahap awal harus memiliki paling sedikit $2 \mathrm{mg}$ 
DO /l. Jika gerakan memutar tidak menyediakan oksigen yang cukup, sistem aerasi tambahan harus dipasang. Biasanya ini mendorong kinerja RBC yang luar biasa, dengan biomassa aerobik yang lebih tipis dan aktif, memungkinkan penghematan biaya yang besar dalam desain dan konstruksi unit RBC.

8. RBC medium submergence

Persentase perendaman sedang RBC tergantung pada beberapa faktor, yaitu jenis operasi, mikroorganisme dan karakteristik limbah yang akan diolah. Biasanya dalam proses aerobik pengolahan air limbah kota, perendamannya sekitar $40 \%$, meskipun dalam pembuangan nutrisi dapat mencapai $60 \%$.

Peningkatan perendaman dikembangkan untuk mengurangi beban poros dan bantalan dan untuk meningkatkan keandalan peralatan. Kontaktor biologis terendam (SBC), sebagaimana disebut, beroperasi pada 70-90\% perendaman yang memberikan keuntungan dari volume media yang lebih besar yang tersedia dan lebih sedikit unit SBC yang dibutuhkan. Perendaman lebih dari 50\% akan menurunkan laju transfer oksigen dalam sistem, sehingga jika SBC digunakan untuk mengolah air limbah secara aerobik; unit penggerak udara tambahan untuk memberikan oksigen dan rotasi harus digunakan.

\section{Kelebihan RBC}

Proses pengolahan air limbah menggunakan RBC memiliki beberapa kelebihan dibandingkan dengan pengolahan lainnya, diantaranya (Tang Yun-lu,et.al, 2012) :

1. Pengoperasian yang mudah dan perawatan yang mudah,

2. Tidak membutuhkan lahan yang terlalu besar jika dibandingkan dengan trickling filter karena trickling filter membutuhkan lahan yang lebih besar,

3. Penggunaan energi yang lebih rendah,

4. Lumpur yang dihasilkan lebih sedikit,

5. Lebih tahan terhadap fluktuasi beban pengolahan karena dapat dipasang beberapa stage (multi stage)

6. Efisiensi removal ammonium lebih besar karena reaksi nitrifikasi mudah terjadi,

7. Pada proses lumpur aktif tidak menimbulkan bulking atau buth (foam).

\section{PENUTUP}

Rotating Biological Contactor (RBC) telah banyak digunakan dalam berbagai aplikasi perawatan. Namun, karena pola aliran yang kompleks di mana aerasi, transfer massa nutrisi dan oksigen, pertumbuhan biofilm dan detasemen, dan partisipasi biomassa tersuspensi harus dipertimbangkan. Peningkatan rasio submergensi pada tahap pertama meningkatkan denitrifikasi. Namun, mengubah perendaman mempengaruhi efisiensi penghilangan nutrisi lain dan tingkat perendaman $40-42 \%$ adalah optimal untuk semua tahap dan menunjukkan hasil terbaik.

\section{DAFTAR PUSTAKA}

Aleksandra Ziembińska-Buczyńska, Sławomir Ciesielski, Sebastian Żabczyński, Grzegorz Cema. 2019. Bacterial Community Structure in Rotating Biological Contactor Treating Coke Wastewater in Relation to Medium Composition. International Journal of Energy and Water Resources

DOI : https://doi.org/10.1007/s11356-019-05087-0

Atieh Ebrahim, Ghasem D. NAjafpour, Michael Anazadeh, Mohammad Gavami. 2018. Optimization of Whey Treatment in Rotating Biological Contactor: Application of Taguchi Method. Iranian Journal Of Energy \& Environment. 
DOI: 10.5829/IJEE.2018.09.02.10

Joanna Szulżyk-Cieplak, Aneta Tarnogórska, Zygmunt Lenik. 2018. Study on the Influence of Selected Technological Parameters of a Rotating Biological Contactor on the Degree of Liquid Aeration. Journal of Ecological Engineering. 19(6):247253

DOI: https://doi.org/10.12911/22998993/92512

Nishi Verma, Martin Anda, Yureana Wijayanti. 2019. Artificial Recharge For Sustainable Groundwater Management Plan in Yogyakarta. Indonesian Journal of Urban and Environmental Technology

DOI : http://dx.doi.org/10.25105/urbanenvirotech.v2i2.4364

Rininta Triananda Noor, Prayatni Soewondo. 2018. Selection of Domestic Wastewater Treatment Technology Alternative Using Life Cycle Assessment (LCA) Approach (Case Study: Settlement Area of Riverbank Karang Mumus of Samarinda City, East Kalimantan). Indonesian Journal of Urban and Environmental Technology

DOI: http://dx.doi.org/10.25105/urbanenvirotech.v1i2.2825

Rongjun Su, Guangshan Zhang, Peng Wang, Shixiong Li, Ryan M. Ravenelle, John C. Crittenden. 2015. Treatment of Antibiotic Pharmaceutical Wastewater Using a Rotating Biological Contactor. Hindawi Journal of Chemistry DOI : http://dx.doi.org/10.1155/2015/705275

Tang Yun-lu, Liu Dong-fang, Meng Xian-rong, Yu Jie, Wang Jin, Liu Yu-xing, Li Kexun, James Lander. 2012. Performance of a modified RBC system in simulated municipal wastewater treatment. Water Science and Technology

DOI: https://doi.org/10.2166/wst.2012.412

Tsukasa Ito, Toru Aoi, Naoki Miyazato, Masashi Hatamoto. 2019. Diversity and abundance of denitrifying bacteria in a simultaneously nitrifying and denitrifying rotating biological contactor treating real wastewater at low temperatures. H2Open Journal DOI: https://doi.org/10.2166/h2oj.2019.021

V. Singh, A. K. Mittal. 2012. Characterization of biofilm of a rotating biological contactor treating synthetic wastewater. Water Science and Technology DOI: https://doi.org/10.2166/wst.2012.221 